Artikel Penelitian

\title{
Efek Pemberian Vitamin C terhadap Mikroskopis Ginjal Tikus Wistar yang Terpapar Plumbum Asetat
}

\author{
Zaki Farhan ${ }^{1}$, M. Setia Budi ${ }^{2}$, Elmatris ${ }^{3}$
}

\section{Abstrak}

Plumbum merupakan salah satu logam berat yang terkandung dalam bahan bakar kendaraan bermotor. Plumbum diekskresikan melalui ginjal sehingga dalam jangka waktu yang lama akan menyebabkan kerusakan sel epitel tubulus proksimal. Vitamin C merupakan salah satu senyawa yang bersifat antioksidan yang dapat melindungi efek radikal bebas yang ditimbulkan oleh plumbum. Tujuan penelitian ini adalah menentukan efek pemberian vitamin $\mathrm{C}$ terhadap mikroskopis ginjal tikus Wistar yang terpapar plumbum asetat. Penelitian ini merupakan studi eksperimental post test only control group design. Subjek penelitian adalah 24 ekor tikus Wistar jantan yang dibagi menjadi empat kelompok, yaitu $\mathrm{K}$ - tanpa perlakuan, $\mathrm{K}+$ dengan pemberian $\mathrm{Pb}$ asetat $50 \mathrm{mg} / \mathrm{kgbb} / \mathrm{hari}, \mathrm{P} 1$ dengan pemberian $\mathrm{Pb}$ asetat dan vitamin C $50 \mathrm{mg} / \mathrm{kgbb} / \mathrm{hari}$, dan $\mathrm{P} 2$ dengan pemberian $\mathrm{Pb}$ asetat dan vitamin $\mathrm{C} 75 \mathrm{mg} / \mathrm{kgbb} / \mathrm{hari}$. Masingmasing kelompok terdiri dari enam ekor tikus dengan perlakuan selama empat minggu. Hasil penelitian menunjukkan bahwa terjadi kerusakan tubulus proksimal ginjal yang berbeda secara bermakna pada kelompok K+, P1, P2 dibandingkan dengan kelompok K- serta perbedaan yang bermakna pada kelompok P1, P2 terhadap kelompok K+ $(p$ $<0,05)$. Terdapat efek pemberian vitamin $C$ terhadap mikroskopis ginjal tikus Wistar terhadap paparan plumbum asetat dengan dosis $50 \mathrm{mg} / \mathrm{kgbb} / \mathrm{hari}$. Simpulan hasil penelitian ini adalah terjadi perubahan mikroskopis ginjal tikus Wistar yang terpapar plumbum asetat dengan dosis $50 \mathrm{mg} / \mathrm{kgbb} / \mathrm{hari}$.

Kata kunci: plumbum asetat, gambaran mikroskopis ginjal, vitamin $\mathrm{C}$, tubulus proksimal

\section{Abstract}

Lead is one of the heavy metals contained in motor vehicle exhaust fumes. Lead is excreted through the kidney, in a longer period of time can damage proximal tubular epithelial cells. Vitamin $C$ is one of antioxidant compounds that can protect from the effects of free radicals by lead compound. The objectives of this studi was to determine the effects of vitamin $C$ on microscopic of kidney were exposed lead acetate. The research is experimental research with post-test only control group design. The subjects were 24 male Wistar rats those were divided into four groups, $K$ - not exposed, $K+$ was given lead asetat $50 \mathrm{mg} / \mathrm{kgbw} /$ day, $P 1$ was given lead asetat and vitamin C 50 $\mathrm{mg} / \mathrm{kgbw} /$ day, and P2 was given lead asetat and vitamin $C 75 \mathrm{mg} / \mathrm{kgbw} /$ day. Each group consists of six was given group for four weeks. The results showed that occurs damage proximal tubular epithelial cells of kidney significantly different to the group $K+, P 1, P 2$ compared with $K$ - and $P 1, P 2$ compared with $K+(p<0,05)$. There is the effect of vitamin $C$ on microscopic on rat's kidney were exposed lead acetate with dose $50 \mathrm{mg} / \mathrm{kg} \mathrm{bw} / \mathrm{day}$. The conclusion of this research was caused changes on microscopic of kidney were exposed lead acetate with dose $50 \mathrm{mg} / \mathrm{kgbw} / \mathrm{day}$.

Keywords: lead acetate, kidney microscopic appeareance, vitamin C, proximal tubular

Affiliasi penulis: 1. Prodi Profesi Dokter FK Unand (Fakultas Kedokteran Universitas Andalas Padang), 2. Bagian Anatomi FK Unand, 3. Bagian Kimia FK Unand

Korespondensi: Zaki Farhan , Email :zakifarchan@gmail.com, Telp: 085669082193

\section{PENDAHULUAN}

Manusia dapat terpapar logam berat di lingkungan kehidupan sehari-hari. Salah satu logam berat yang dapat menyebabkan keracunan adalah plumbum. Keracunan logam berat ini bersifat kumulatif 
dan dalam jangka waktu yang panjang akan menimbulkan keracunan kronis di dalam tubuh. Keracunan kronis tersebut akan berpengaruh terhadap kerusakan otak, ginjal, hati, sistem saraf, sel darah merah maupun organ lainnya. ${ }^{1}$

Tetraetil plumbum merupakan zat tambahan pada bahan bakar kendaraan bermotor yang berfungsi sebagai peredam suara dan meningkatkan daya kerja mesin. Gas buangan dari kendaraan bermotor akan mengakibatkan terjadinya paparan senyawa plumbum sehingga plumbum dapat bersumber melalui udara yang akan masuk ke tubuh manusia melalui saluran pernafasan. $^{2}$ Senyawa plumbum organik dapat bereaksi sebagai gas dalam saluran pernafasan dan diserap dalam tingkat yang lebih besar daripada partikel senyawa plumbum anorganik, sehingga dalam dosis kecil sudah dapat menyebabkan efek toksik bagi tubuh. $^{3}$

Absorbsi plumbum terjadi melalui saluran pernafasan, saluran pencernaan dan kulit. Absorbsi terbanyak dari plumbum melalui saluran pernafasan, yaitu sekitar $35-50 \%$. Setelah diabsorbsi, plumbum didistribusikan oleh darah dan diekskresikan melalui urin sebanyak $75-80 \%{ }^{4}$ Berdasarkan penelitian Nasution (2010), pemberian plumbum asetat 100 $\mathrm{mg} / \mathrm{kgBB} /$ hari pada minggu ke-8 terjadi perubahan warna dan permukaan dari ginjal menjadi tampak lebih pucat yang disertai bintik putih dan struktur permukaannya bernodul-nodul. Pada kelompok kontrol tidak mengalami perubahan warna dan permukaan. ${ }^{5}$ Pada penelitian Hariono (2006), terlihat gambaran makroskopis ginjal dan hati tampak pucat dan sedikit kekuningan pada tikus kelompok perlakuan yang diberikan trietil plumbum asetat dengan dosis 1,5 $\mathrm{mg} / \mathrm{kgBB} /$ hari sejak minggu ke-6 sampai minggu ke10. Jaringan tubuh yang lain termasuk sumsum tulang terlihat normal. ${ }^{2}$

Senyawa radikal bebas dapat dibentuk di dalam sel tubuh melalui reaksi enzimatik dan nonenzimatik. Reaksi enzimatik terlibat dalam rantai pernafasan, fagositosis, sintesis prostaglandin, dan sistem P-450 sitokrom. Radikal bebas juga dapat terbentuk oleh reaksi non-enzimatik dari oksigen dengan senyawa organik. Senyawa tetraetil plumbum merupakan senyawa organik yang akan berubah di dalam tubuh menjadi trietil plumbum. Apabila trietil plumbum bereaksi dengan oksigen di dalam tubuh akan terbentuk suatu radikal bebas. Radikal bebas akan menyerang makromolekul penting, seperti DNA, protein, karbohidrat dan lipid yang dapat menyebabkan kerusakan sel dan gangguan homeostasis. ${ }^{6}$ Untuk mengatasi dampak negatif dari radikal bebas dapat digunakan antioksidan. Antioksidan merupakan senyawa yang dapat mengatasi dampak negatif dari oksidan, termasuk di dalamnya enzim-enzim dan protein pengikat logam, seperti vitamin $\mathrm{C}^{7}$

Berdasarkan penelitian Fauzi (2008), pemberian vitamin $C$ dengan dosis $0,2 \mathrm{mg} / \mathrm{g} B B$ secara oral selama 36 hari sudah dapat berperan sebagai antioksidan untuk menetralisir atau melindungi efek senyawa radikal bebas yang dapat ditimbulkan oleh senyawa plumbum asetat $0,1 \%$ yang ditandai dengan penurunan kadar MDA di dalam sekresi epididimis. ${ }^{8}$

\section{METODE}

Jenis penelitian yang dilakukan adalah penelitian eksperimental dengan desain postest only control group design. Populasi penelitian ini adalah tikus yang berumur 2-3 bulan yang sehat dan ditandai dengan gerakan aktif. Sampel berjumlah 28 ekor tikus Wistar jantan umur 2-3 bulan dengan berat badan 150-250 gram yang diambil berdasarkan metode Simple Random Sampling.Penelitian ini dilakukan di laboratorium Fakultas Farmasi UNAND dan di laboratorium Patologi Anatomi Fakultas Kedokteran UNAND dari bulan Juni-Desember 2013.

Variabel dependen penelitian adalah gambaran mikroskopik ginjal tikus Wistar yang di dapatkan dengan menghitung jumlah sel tubulus proksimal abnormal dengan menggunakan alat ukur mikroskop perbesaran 400 kali dalam lima lapangan pandang. Normal apabila tampak sel berbentuk poligonal, sitoplasma berwarna merah homogen, dinding sel berbatas tegas, dan terdapat brush border.Abnormal apabila terdapat vakuolisasi intrasitoplasmik, degenerasi hidrofik, pelebaran lumen tubulus, dan nekrosis.

Variabel independen penelitian adalah tanpa dan dengan pemberian plumbum asetat dan vitamin $\mathrm{C}$ 
yang terbagi menjadi empat kelompok, yaitu; (K-) tanpa perlakuan, $(\mathrm{K}+)$ pemberian plumbum asetat dengan dosis $50 \mathrm{mg} / \mathrm{kgBB} / \mathrm{hari}$, (P1) plumbum asetat $50 \mathrm{mg} / \mathrm{kgBB} / \mathrm{hari}$ yang ditambah dengan pemberian vitamin C50 mg/kgBB/hari, (P2) plumbum asetat 50 $\mathrm{mg} / \mathrm{kgBB} /$ hari yang ditambah dengan pemberian vitamin C $75 \mathrm{mg} / \mathrm{kgBB} /$ hari.

Analisis data dilakukan dengan menggunakan uji One-Way-ANOVA. Syarat untuk menggunakan uji One-Way-ANOVA adalah distribusi data harus normal. Apabila distribusi data tidak normal dilakukan transformasi untuk menormalkan data. Apabila masih belum memenuhi syarat, dilakukan analisis data dengan menggunakan uji Kruskal-Wallis. Analisis data bermakna apabila $p<0,05$.

HASIL

\section{Gambaran Mikroskopis Ginjal Tikus Wistar Normal} dan Setelah Terpapar Plumbum Asetat.

Terdapat perbedaan secara mikroskopis dari jumlah rata-rata sel abnormal dan jenis kerusakan sel tubulus proksimal pada kelompok tikus yang normal (K-) dengan tikus yang terpapar plumbum asetat $(\mathrm{K}+)$.

Tabel 1. Jumlah rata-rata sel normal dan abnormal ginjal pada kelompok kontrol negatif (K-) dan setelah pemberian plumbum asetat $(\mathrm{k}+)$.

\begin{tabular}{ccc}
\hline $\begin{array}{c}\text { Kelompok } \\
(\mathbf{n}=6)\end{array}$ & $\begin{array}{c}\text { Rata -rata sel } \\
\text { Normal }\end{array}$ & $\begin{array}{c}\text { Rata-rata sel } \\
\text { Abnormal }\end{array}$ \\
\hline $\mathrm{K}-$ & 111,83 & 0 \\
$\mathrm{~K}+$ & 88,17 & 17,5 \\
\hline
\end{tabular}

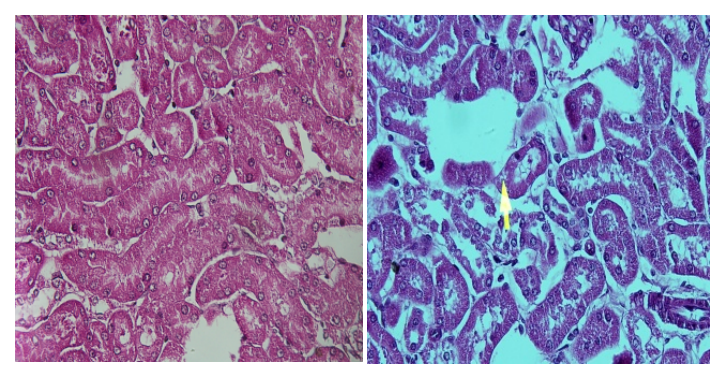

Gambar 1. Gambaran mikroskopis ginjal tikus Wistar pada kelompok kontrol; (Kiri) tubulus proksimal pada kontrol negatif, (Kanan) vakuolisasi pada $\mathrm{K}+$

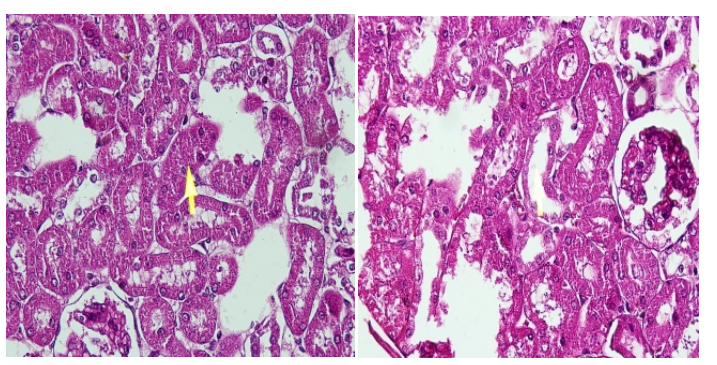

Gambar 2. Gambaran mikroskopis ginjal tikus Wistar pada kelompok kontrol; (Kiri) degenerasi hidrofik pada $\mathrm{K}+$, (Kanan) pelebaran lumen pada $\mathrm{K}+$.

\section{Gambaran Mikroskopis Ginjal Tikus Wistar Setelah Terpapar Plumbum Asetat Dengan dan Tanpa Pemberian Vitamin C \\ Terdapat perbedaan secara mikroskopis dari} jumlah rata-rata sel abnormal dan jenis kerusakan sel tubulus proksimal pada kelompok tikus yang terpapar plumbum asetat $(\mathrm{K}+)$ dengan tikus yang terpapar plumbum asetat setelah pemberian vitamin $\mathrm{C}(\mathrm{P} 1, \mathrm{P} 2)$.

Tabel 2. Jumlah rata-rata sel normal dan abnormal ginjal yang terpapar plumbum asetat setelah pemberian vitamin $\mathrm{C}$ dengan dosis $50 \mathrm{mg} / \mathrm{kgbb} / \mathrm{hari}$ dan $75 \mathrm{mg} / \mathrm{kgbb} / \mathrm{hari}$.

\begin{tabular}{ccc}
\hline $\begin{array}{c}\text { Kelompok } \\
(\mathbf{n = 6})\end{array}$ & $\begin{array}{c}\text { Rata -rata sel } \\
\text { Normal }\end{array}$ & $\begin{array}{c}\text { Rata-rata sel } \\
\text { Abnormal }\end{array}$ \\
\hline $\mathrm{K}+$ & 88,17 & 17,5 \\
P1 & 105,67 & 3,17 \\
P2 & 105,00 & 1,33 \\
\hline
\end{tabular}

Berdasarkan Tabel 3 dapat dilihat bahwa pada kelompok $\mathrm{K}+$ ditemukan adanya kerusakan berupa vakuolisasi intrasitoplasmik, dgenerasi hidrofik, dan pelebaran lumen tubulus. Akan tetapi, pada kelompok P1 dan P2 masih ditemukan adanya kerusakan berupa vakuolisasi intrasitoplasmik dan degenerasi hidrofik. 
Tabel 3. Gambaran kerusakan sel tubulus proksimal ginjal tikus wistar yang terpapar plumbum asetat setelah pemberian vitamin C dengan dosis 50 $\mathrm{mg} / \mathrm{kgbb} / \mathrm{hari}$ dan $75 \mathrm{mg} / \mathrm{kgbb} /$ hari.

\begin{tabular}{ccccc} 
& $\begin{array}{l}\text { Vakuolisasi } \\
\text { Intra } \\
\text { sitoplasmik }\end{array}$ & $\begin{array}{l}\text { Degenerasi } \\
\text { Hidrofik }\end{array}$ & $\begin{array}{l}\text { Pelebaran } \\
\text { Lumen } \\
\text { Tubulus }\end{array}$ & Nekrosis \\
\hline $\mathrm{K}+$ & + & + & + & - \\
$\mathrm{P} 1$ & + & + & - & - \\
$\mathrm{P} 2$ & + & + & - & - \\
\hline
\end{tabular}
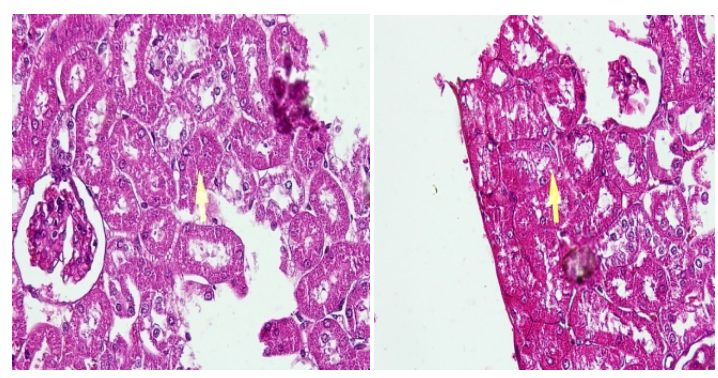

Gambar 3. Gambaran mikroskopis ginjal tikus Wistar pada kelompok perlakuan; (Kiri) degenerasi hidrofik pada P1, (Kanan) vakuolisasi pada P2.

\section{Analisis Data Gambaran Mikroskopis Ginjal Tikus Wistar yang Terpapar Plumbum Asetat Setelah Pemberian Vitamin C}

Tabel 4. Analisis data jumlah rata-rata sel abnormal dari tubulus proksimal ginjal yang terpapar plumbum asetat setelah pemberian vitamin $\mathrm{C}$ dengan dosis 50 $\mathrm{mg} / \mathrm{kgbb} /$ hari dan $75 \mathrm{mg} / \mathrm{kgbb} /$ hari.

\begin{tabular}{ccc}
\hline $\begin{array}{c}\text { Kelompok } \\
(\mathbf{n = 6})\end{array}$ & Rerata Geometrik & $\mathbf{p}$ \\
\hline $\mathrm{K}+$ & 17,6035 & \\
P1 & 2,9936 & $\mathbf{0 , 0 0 0}$ \\
P2 & 1,3195 &
\end{tabular}

Uji One Way Anova.Uji Post-Hoc LSD: K+ vs P1, p $=0,000 ; \mathrm{K}+$ vs $\mathrm{P} 2, \mathrm{p}=0,000 ; \mathrm{P} 2$ vs $\mathrm{P} 1, \mathrm{p}=0.005$.

Pada analisis data dengan uji One-Way Anova hasil pengukuran persentase sel abnormal diperoleh nilai $p<0,05$, sehingga diambil kesimpulan paling tidak terdapat perbedaan yang bermakna dari semua kelompok. Selanjutnya pada analisis data dengan uji Post-Hoc ditemukan bahwa terdapat pengaruh signifikan $(p<0,05)$ pada kelompok kontrol positif $(\mathrm{K}+)$ terhadap perlakuan satu $(\mathrm{P} 1)$, kontrol positif $(\mathrm{K}+)$ terhadap perlakuan dua $(\mathrm{P} 2)$, dan perlakuan 1 (P1) terhadap perlakuan 2 (P2).

\section{PEMBAHASAN}

Hasil analisis data penelitian dari jumlah kerusakan sel menunjukkan bahwa pada tikus dengan tanpa pemberian plumbum asetat dan vitamin $C$ tidak ditemukan adanya kerusakan berupa sel abnormal pada tubulus proksimal ginjal. Pada pemberian plumbum asetat dengan dosis $50 \mathrm{mg} / \mathrm{kgbb} / \mathrm{hari}$ sudah memberikan dampak kerusakan terhadap tubulus proksimal ginjal tikus Wistar. Secara statistik berdasarkan uji One-Way anova dan dilanjutkan dengan uji Post-Hoc didapatkan nilai $p<0,05$, artinya terdapat perbedaan yang bermakna antara kelompok yang tidak diberi plumbum asetat dengan kelompok yang diberi plumbum asetat. Hal ini didukung oleh penelitian Hariono (2006) bahwa terdapat efek pemberian plumbum terhadap makroskopis dan mikroskopis ginjal dengan ditemukan adanya perubahan yang signifikan terhadap berat badan tikus dan berat ginjal. ${ }^{2}$

Penelitian terdahulu juga disebutkan bahwa terdapat pengaruh plumbum terhadap manusia pada dosis tertentu sehingga bersifat toksik terhadap manusia. Dosis plumbum $600 \mathrm{mg} / \mathrm{kgBB}$ merupakan dosis keseimbangan. Dosis plumbum $2.500 \mathrm{mg} / \mathrm{kgBB}$ menyebabkan keracunan dalam waktu 3 tahun. Sedangkan pada tikus dosis yang dapat menyebabkan toksik apabila kadar plumbum $100 \mathrm{mg} / \mathrm{kgBB}^{9}$

Pada penelitian ini juga menunjukkan bahwa terdapat efek pemberian vitamin $C$ terhadap kerusakan yang diakibatkan oleh plumbum asetat. Hal ini didukung oleh penelitian Doloksaribu (2008), menunjukkan bahwa terjadi peningkatan berat badan pada tikus yang diberi vitamin $C$ dengan dosis 1000 $\mathrm{mg} / \mathrm{kgBB} / \mathrm{hari}$ terhadap paparan plumbum asetat dengan dosis $20 \mathrm{mg} / \mathrm{kgBB} / \mathrm{hari}$. Sedangkan tikus yang diberi paparan plumbum asetat $20 \mathrm{mg} / \mathrm{kgBB} / \mathrm{hari}$ mengalami penurunan berat badan. ${ }^{7}$

Data jenis kerusakan ginjal ditemukan adanya kerusakan berupa vakuolisasi intrasitoplasmik, degenerasi hidrofik, dan pelebaran lumen tubulus proksimal ginjal setelah pemberian plumbum asetat 50 
$\mathrm{mg} / \mathrm{kgbb} / \mathrm{hari}$. Pada pemberian vitamin $\mathrm{C}$ dan plumbum asetat tidak ditemukan adanya peleberan lumen tubulus, tetapi masih ditemukan kerusakan berupa vakuolisasi intrasitoplasmik dan degenerasi hidrofik. Pada penelitian ini ditemukan adanya perubahan yang signifikan dengan nilai $p<0,05$ yang sejalan dengan penelitian Nasution dengan ditemukan adanya perubahan yang signifikan terhadap makroskopis dan mikroskopis ginjal yang ditandai dengan kerusakan sel tubulus proksimal, seperti degenerasi, hiperplasia, kariomegali, pelebaran lumen tubulus dan adanya benda inklusi dalam inti sel. ${ }^{5}$

Pada penelitian eksperimental sebelumnya ditemukan bahwa terdapat pengaruh plumbum terhadap gambaran histopatologi ginjal. Selain plumbum, cadmium yang juga merupakan salah satu logam berat dapat berpengaruh terhadap kerusakan histopatologi ginjal dengan ditemukan adanya degenerasi tubulus. ${ }^{10}$ Penelitian lain yang menemukan bahwa terjadinya kerusakan mitokondria yang merupakan sebagian besar terdapat pada sel epitel tubulus proksimal ginjal akibat dari paparan plumbum dengan ditandai adanya kehilangan krista. ${ }^{11}$

Nekrosis Tubular Akut (ATN) merupakan kesatuan klinikopatologi yang ditandai secara morfologik oleh destruksi sel epitel tubulus dan secara klinik oleh supresi akut fungsi ginjal dan sebagai penyebab paling umum gagal ginjal akut. Sejumlah logam berat atau kontak dengan bahan yang diekskresikan melalui ginjal akan menyebabkan sel epitel tubulus peka terhadap anoksia dan mudah hancur, sehingga terbentuk jejas tubuler dan menyebabkan ATN nefrotoksik. ${ }^{12}$ Salah satu logam berat yang dapat menyebabkan kerusakan sel epitel tubulus adalah plumbum. Akumulasi plumbum dapat menyebabkan terjadinya respon radang akut yang dapat mengakibatkan vasodilatasi dan ekstravasasi cairan serta terjadinya difusi cairan ke intraseluler sehingga terbentuk suatu vakuol dan tonjolan dari sitoplasma sel tubulus proksimal yang dapat menyebabkan penyempitan tubulus. Disamping itu, tonjolan yang terbentuk dapat pecah dan terjadinya obstruksi sehingga lama-kelamaan penyempitan tubulus akan berubah menjadi penutupan lumen tubulus atau disebut juga dengan degenerasi hidrofik. Akumulasi plumbum yang bersifat kronis akan menyebabkan terjadinya destruksi sel epitel tubulus setelah terbentuk degenerasi hidrofik sehingga berakibat pada nekrosis tubular akut (ATN). ${ }^{13}$

Pada penelitian eksperimental sebelumnya juga ditemukan efek pemberian vitamin $C$ terhadap aktivitas Superoksida Dismutase (SOD), katalase, dan glutation peroksidase yang terpapar oleh plumbum didapatkan adanya perbedaan bermakna $(p<0,05)$. Hal ini didapatkan hasil bahwa terdapat peningkatan aktifitas superoksida dismutase (SOD), katalase, dan glutation peroksidase di dalam darah. ${ }^{14}$ SOD merupakan golongan enzim antioksidan yang penting dalam pendekomposisian katalik radikal superoksida menjadi hidrogen peroksida dan oksigen. Katalase secara spesifik mengkatalis dekomposisi hidrogen peroksida. Glutation peroksidase merupakan golongan enzim antioksidan yang mengandung selenium yang penting dalam mengurangi hidroperoksida, sebagai contoh: hasil oksidasi lipid. ${ }^{8}$

Penelitian efek pemberian vitamin $\mathrm{C}$ terhadap gambaran mikroskopis ginjal tikus Wistar yang terpapar oleh plumbum asetat ini telah dilakukan sesuai dengan prosedur yang seharusnya, namun masih terdapat beberapa keterbatasan dalam pelaksanaannya. Keterbatasan tersebut diantara lain adalah kurang tersedianya fasilitas penelitian yang memadai, contohnya kandang yang nyaman untuk hewan percobaan. Meskipun penelitian ini memiliki keterbatasan, namun diharapkan tetap dapat memberikan manfaat untuk mengetahui dampak plumbum.

\section{SIMPULAN}

Terdapat efek pemberian vitamin C terhadap mikroskopis ginjal tikus Wistar terhadap paparan plumbum asetat dengan dosis $50 \mathrm{mg} / \mathrm{kgbb} /$ hari. Hal ini terjadi karena perubahan mikroskopis ginjal tikus Wistar yang terpapar plumbum asetat dengan dosis 50 $\mathrm{mg} / \mathrm{kgbb} / \mathrm{hari}$. 


\section{DAFTAR PUSTAKA}

1. Sari $\mathrm{DH}$. Pengaruh Timbal $(\mathrm{Pb})$ pada udara jalan tol terhadap gambaran mikroskopis ginjal dan kadar timbal $(\mathrm{Pb})$ dalam darah mencit BALB/C jantan. (Laporan Hasil Akhir Penelitian Karya Tulis IImiah). Semarang: Universitas Diponegoro; 2010.

2. Hariono B. Effect of organic lead administration in rats (Rattus novergicus). J.SainVet. 2006;24(1): 125-34.

3. World Health Organization (WHO). Inorganic and organic lead compound. International Agency for Research On Cancer. 2006 (diunduh 5 Maret 2013). Tersedia dari: URL: HYPERLINK http://monographs.iarc.fr/ENG/Monographs/vol87/v olume87.pdf

4. Health Protection Agency (HPA). Lead toxicological overview. 2012 (diunduh 13 Februari 2013). Tersedia dari: URL: HYPERLINK http://hpa.org.uk/webc/HPAwebFile/HPAweb C/11 $\underline{94947332124}$

5. Nasution AH. Gambaran makroskopis dan mikroskopis ginjal mencit (Mus musculus) akibat pemberian $\mathrm{Pb}$ asetat dan rosella (Hibiscus Sabdariffa). (Laporan Hasil Akhir Penelitian Karya Tulis IImiah). Medan: Universitas Sumatera Utara; 2010.

6. Lobo V, Patil A, Phatak A, Chandra N. Free radicals, antioxidants and functional foods: Impact on human health. Pharmacognosy Review. 2010;8(4):118-26.

7. Doloksaribu B. Pengaruh proteksi vitamin C terhadap kadar ureum, kreatinin dan gambaran histopatologis ginjal mencit yang dipapar plumbum. Medan: Universitas Sumatera utara; 2008.

8. Fauzi TM. Pengaruh pemberian timbal asetat dan vitamin C terhadap kadar malondialdehyde dan kualitas spermatozoa di dalam sekresi epididimis mencit albino (Mus musculus L) Strain BALB/C. Medan: Universitras Sumatera utara; 2008.

9. Putra ST, Musta'lina S, Soehadi K. The Influence of $\mathrm{Pb}$ asetate toward the decrease of imunological mucosal system within Mus musculus BALB/C Intestine. Folia Medica Indonesiana. 2000;36:12-8.

10. Salinska A, Wlowstowski T, Zambrzycka E. Effect of dietary cadmium and/pr lead. On histopathological changes in the kidneys and liver of bank Myodes Glareolus kept in group densities. Ecotoxicology. 2012;21: 2234-43.

11. Wang $L$, Jianji $L$, Jingui $L$, Zongping $L$. Effects of lead and/or cadmium on the oxidative damage of rat kidney cortex mitochondria. Biol Trace Elem Res. 2010;137:69-78.

12. Robbins SL, Kumar V, Cotran RS. Buku ajar patologi, Edisi ke-7. Jakarta: EGC; 2002. hlm. 312-4.

13. Jennette JC, Olson JL, Schwart MM, Silva FG. Heptintall's pathology of kidney. Edisi ke-6. 2007; 2:863-7.

14. Nisar NA, Sultana M, Waiz HA, Para PA. Experimental study on the effect of vitamin $C$ adminstration on lipid peroxidation and antioxidant enzyme activity in rats exposed to chlopyriphos and lead asetate. Vetworld. 2013:461-6. 